\title{
A HAZÁNKBA BEVÁNDORLÓK TERÜLETI ELHELYEZKEDÉSÉNEK VIZSGÁLATA ${ }^{1}$
}

\author{
(Examining Regional Distribution of Immigrants in Hungary)
}

\section{TÓTH GÉZA - KINCSES ÁRON}

Kulcsszavak:

bevándorlók útelemzés potenciálmódszer

A tanulmány a hazánkba bevándorlók terïleti sajátosságait vizsgálja. Feltárjuk a bevándorlás okait, annak nemzeti különbségeit. Útelemzés segítségével elemezzük a migránsok aránya és a közúti elérhetōség közötti kapcsolatokat. Vizsgáljuk a bevándorló és a már hazánkban élö migránsok elhelyezkedésének kapcsolatát, végül potenciálmódszer segítségével feltárjuk a bevándorlók kistérségi szintü megoszlasának térszerkezeti kullönbségeit.

\section{Bevezetö}

A rendszerváltás óta hazánk nemzetközi vándorlási többlettel rendelkezik. Azaz, több külföldi érkezik Magyarországra, mint ahány honfitársunk elhagyja azt. A külföldiek hatása egyre nagyobb. Míg 30-40 000 före tehető az éves természetes fogyás, addig 10-20000-es éves, pozitív migrációs egyenleg jellemzi Magyarországot. 2008. január 1-jén 174697 külföldi állampolgár tartózkodott huzamosan hazánkban, ez a lakónépesség 1,74\%-a (1. táblázat). Azaz, száz ember közül majdnem kettő külföldi. Az ezredforduló utáni hét évben a külföldiek aránya 61\%-kal növekedett országos átlagban.

1. TÁBLÁZAT
Összefoglaló adatok

(Summary Data)

\begin{tabular}{cccc}
\hline & & \multicolumn{2}{c}{$\begin{array}{c}\text { Magyarországon tartózkodó } \\
\text { külföldi állampolgárok }\end{array}$} \\
\cline { 3 - 4 } & Lakónépesség (január l.) & száma & $\begin{array}{c}\text { az össznépesség } \\
\text { százalékában }\end{array}$ \\
\hline 2001 & 10200298 & 110028 & 1,08 \\
2002 & 10174853 & 116429 & 1,14 \\
2003 & 10142362 & 115888 & 1,14 \\
2004 & 10116742 & 130109 & 1,29 \\
2005 & 10097549 & 142153 & 1,41 \\
2006 & 10076581 & 154430 & 1,53 \\
2007 & 10066158 & 166030 & 1,65 \\
2008 & 10045401 & 174697 & 1,74 \\
\hline
\end{tabular}

Forrás: Saját számítás. 
Tóth Géza - Kincses Áron : A hazánkba bevándorlók területi elhelyezkedésének vizsgálata.

Tér és Társadalom 23. évf. 2009/4. 61-81. p.

62 Tóth Géza-Kincses Áron

TÉT XXIII. évf. 2009

A külföldiek száma hét év alatt több mint másfélszeresére nőtt. Közülük a Kárpátmedence országaiból (Ausztria, Szlovákia, Ukrajna, Románia, Szerbia, Horvátország, Szlovénia) érkezők súlya domináns, és 5\%-kal gyorsabban nő, mint az ezen országokon kívülről érkezőké. Legtöbben Romániából, Ukrajnából, Szerbiából érkeztek hazánkba (2. táblázat). E csoportokon kívül még jelentős számban élnek az EU15 országok állampolgárai (föként németek és osztrákok) is Magyarországon.

A következőkben a szomszédos országok állampolgáraival kiemelten foglalkozunk.

2. TÁBLÁZAT

Magyarországon tartózkodó külföldi állampolgárok állampolgárság szerint (január 1.) (Foreign Citizens Staying in Hungary by Citizenship [1 January])

\begin{tabular}{|c|c|c|c|c|c|c|c|c|}
\hline Ország & 2001 & 2002 & 2003 & 2004 & 2005 & 2006 & 2007 & 2008 \\
\hline Ausztria & 694 & 785 & 750 & 780 & 544 & 1494 & 2225 & 2571 \\
\hline Franciaország & 511 & 601 & 711 & 765 & 330 & 1316 & 1506 & 1481 \\
\hline Hollandia & 324 & 346 & 373 & 415 & 236 & 666 & 1096 & 1201 \\
\hline $\begin{array}{l}\text { Nagy- } \\
\text { Britannia }\end{array}$ & 624 & 700 & 872 & 963 & 440 & 1451 & 1911 & 2107 \\
\hline Németország & 7493 & 7676 & 7100 & 7393 & 6908 & 10504 & 15037 & 14436 \\
\hline Olaszország & 542 & 563 & 545 & 551 & 404 & 777 & 1020 & 1207 \\
\hline$E U-15$ & 11723 & 12181 & 11629 & 12143 & 9714 & 18357 & 25394 & 25490 \\
\hline Horvátország & 917 & 931 & 800 & 902 & 837 & 778 & 813 & 852 \\
\hline Lengyelország & 2279 & 2227 & 1945 & 2196 & 2178 & 2364 & 2681 & 2645 \\
\hline Oroszország & 1893 & 2048 & 1794 & 2244 & 2642 & 2759 & 2760 & 2787 \\
\hline Románia & 41561 & 44977 & 47281 & 55676 & 67529 & 66183 & 66951 & 65836 \\
\hline Szerbia & 12664 & 11975 & 11693 & 12367 & 13643 & 12111 & 12638 & 17186 \\
\hline Szlovákia & 1576 & 2213 & 1536 & 2472 & 1225 & 3597 & 4276 & 4944 \\
\hline Szlovénia & 82 & 88 & 65 & 81 & 34 & 79 & 115 & 133 \\
\hline Törökország & 455 & 544 & 469 & 557 & 615 & 756 & 886 & 1120 \\
\hline Ukrajna & 8947 & 9835 & 9853 & 13096 & 13933 & 15337 & 15866 & 17289 \\
\hline Egyéb európai & 20584 & 21088 & 21552 & 22915 & 24493 & 24307 & 25314 & 26272 \\
\hline $\begin{array}{l}\text { Szomszédos } \\
\text { országok }\end{array}$ & 66359 & 70716 & 71913 & 85293 & 97711 & 99579 & 102769 & 108811 \\
\hline Európa & 93197 & 97640 & 98230 & 110915 & 122261 & 130535 & 140827 & 146145 \\
\hline Ázsia & 12603 & 14401 & 13480 & 14715 & 15121 & 18543 & 19733 & 22356 \\
\hline Amerika & 2488 & 2557 & 2434 & 2535 & 2667 & 2989 & 3075 & 3557 \\
\hline Afrika & 1233 & 1318 & 1281 & 1455 & 1556 & 1800 & 1783 & 1913 \\
\hline $\begin{array}{l}\text { Egyéb és } \\
\text { ismeretlen }\end{array}$ & 507 & 513 & 463 & 489 & 548 & 563 & 612 & 726 \\
\hline Összesen & 110028 & 116429 & 115888 & 130109 & 142153 & 154430 & 166030 & 174697 \\
\hline
\end{tabular}

Forrás: Saját szerkesztés. 
Tóth Géza - Kincses Áron : A hazánkba bevándorlók területi elhelyezkedésének vizsgálata. Tér és Társadalom 23. évf. 2009/4. 61-81. p.

\section{A külföldiek területi elhelyezkedése}

2001-ben a lakónépesség 17\%-a élt Budapesten, 20\%-a megyei jogú városokban, $27 \%$-a egyéb városokban és $36 \%$-a községekben. 2008-ra a városokban lakók aránya $31 \%$-ra nőtt, míg a községeké 32\%-ra csökkent, az első két kategória hozzávetöleges változatlansága mellett.

A külföldiek esetén Budapest eröteljesen felülreprezentált (35\%) volt már 2001-ben is, mely egybeesik a nemzetközi trendekkel, azaz a migráció elsődleges célterületei a fóvárosok. Ezt a hatást az európai kontinensen kívülröl érkezettek határozottabban mutatják (az ázsiaiak 77\%-a lakik a fővárosban). A munkaképes korúak aránya még nagyobb az összes várost figyelembe véve, még a falvakban a nyugdíjasoké jelentős.

A vizsgált hét év alatt egyrészt Budapest vonzó hatása erőteljesen fokozódott a külföldiek körében (43\%), méghozzá a megyei jogú városok arányainak visszaszorulásával (22\%-ról 17\%-ra), a kisebb városok és községek konstans rátái mellett.

\section{A külföldiek területi elhelyezkedésének okai}

A neoklasszikus elmélet szerint makroszinten a tőke és a munkaerő taszító és vonzó tényezői határozzák meg az áramlást. Mikroszinten pedig egyrészt a jövedelmek regionális különbségei jelentik a motivációt a mozgásra (Hatton-Williamson 2005), ahol nagyobb eltérés található a jövedelmek között, ott mobilabb a lakosság. A másik motiváló tényezó a migránsok egyéni képességei, valamint az életkörülmények javítása (Borjas 1996). Véleményünk szerint a külföldiek eloszlásában a szakirodalom által meghatározott legföbb gazdasági motiváló tényezők mellett fontos szerep jut a fóvárosi térségnek, mint jelentős migrációs centrumnak, valamint a határ menti területeknek a vándorlók állampolgárság szerinti országainak közelsége miatt.

A fenti általános megállapítások mellett a Magyarországot érintő migráció esetén - a szomszédos állampolgárok nagy száma miatt - a földrajzi helyzetnek is nagy jelentösége van. Ezt támasztja alá az 1. ábra. A Balaton környéke, Budapest, Pest megye, az ukrán, román-és végül a szerb határ menti kistérségek esetén 2001-ben nagyobb volt a külföldiek aránya, mint máshol. A horvát, szlovén, szlovák és osztrák határ közelében nem alakultak ki hasonló külföldi koncentrációk, ami egyrészt e csoportok magyarországi kisebb számával, másrészt az ukrán, szerb és romản határ mentén elöfordulónál kisebb gazdasági „,potenciál-különbségek”-kel magyarázhatók. 2001-ről 2008-ra éppen a fenti térségekben (centrum és határtérségek) és szomszédságukban növekedett a külföldiek százalékos aránya a lakónépességen belül.

Magyarországon a nemzetközi migránsok területi elhelyezkedésére a következő jellemzö globális szabályszerüséget találtuk. A külföldiek domináns része Budapestre és vonzáskörzetébe került, kisebb hányada a határ menti kistérségekben, illetve a Balaton környékén él. Az EU 15 országok állampolgárai Budapest és vonzáskörzete mellett a nyugati országrészt, főként Győr-Moson-Sopron és Somogy megyét részesítik előnyben. 
Tóth Géza - Kincses Áron : A hazánkba bevándorlók területi elhelyezkedésének vizsgálata.

Tér és Társadalom 23. évf. 2009/4. 61-81. p.

64 Tóth Géza-Kincses Áron

TÉT XXIII. évf. 2009

\section{1. ÁBRA}

Külföldiek aránya 100 lakosra, 2001. jan. 1.; 2008. jan. 1.

(Share of Foreigners per 100 Residents, 1 January 2001; 1 January 2008)
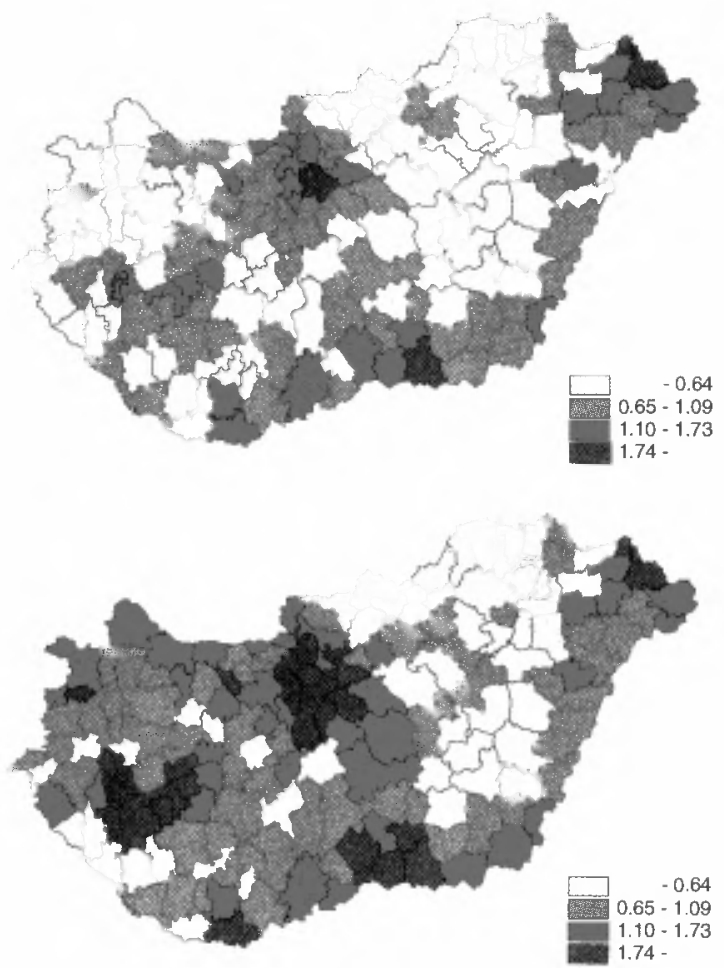

Forrás: Saját szerkesztés.

A román állampolgárok elhelyezkedése a leginkább megosztott; a román határ mentén, a fövárosban, és Nyugat-Magyarországon is jelentős számban élnek. A szerbek a közös határunk és Budapest által meghatározott ék alakban tömörülnek. A szlovákok Észak-Magyarországon és Budapest környékén koncentrálódnak, míg az ukránok számára Budapest mellett szintén a küldö országukhoz közeli kistérségek a legvonzóbbak. Összefoglalva elmondható, hogy a szomszédos országokból Magyarországon tartózkodó külföldiek számára Budapest és Pest megye egyöntetüen vonzó célpontot jelent, emellett elönyben részesítik az allampolgárságuknak megfelelö országhoz közelebb esö kistérségeket, föként a román, ukrán és szerb határ közelében. Fontos megjegyezni azt is, hogy ott is mutatnak letelepedési érdeklödést a külföldiek, ahol szükséges a „humán erőforrás injekció”, mint a Dél-Dunántúl vagy Északkelet-Magyarország. 
Tóth Géza - Kincses Áron : A hazánkba bevándorlók területi elhelyezkedésének vizsgálata. Tér és Társadalom 23. évf. 2009/4. 61-81. p.

Korábban a telephelyelméletek a határrégiókat tradicionálisan hátrányos területként szemlélték, elsôsorban a nemzetközi kereskedelmi áramlatokat elválasztó határok és a lehetséges katonai inváziók miatti fenyegetettség következtében (Anderson-O'Down 1999). A nemzeti határok negatívan hatnak a regionális gazdaságra, mivel mesterségesen vágják szét a térben összekapcsolódó régiókat, s növelik a tranzakciós költségeket. Az eltérô adók, a különböző nyelvek, kultúrák (a szóban forgó határok esetén ez utóbbi két eset nem állja meg a helyét) és üzleti gyakorlatok gátolják a határon átnyúló kereskedelmet - ezek a határrégiók potenciális politikai és szociális instabilitásának az alapjai -, mely akadályozza a hazai és külföldi gyártók letelepedését ezekben a régiókban (Hansen 1977).

Ennek a kedvezótlen képnek a megváltoztatása, a nagyobb nemzetközi gazdasági integrációnak köszönhetően - a kereskedelmi korlátok és a nemzeti határok eliminálása segítségével - új növekedési perspektívát jelent a határrégiókban, elsősorban a nagy potenciális piacok földrajzi megközelíthetősége miatt, amint az megtörtént 1993-ban Európában az egységes piac realizálásával, és a NAFTA megalkotása után Észak-Amerikában (Nijkamp 1998; Van Geenhuizen-Ratti 2001).

\section{Útelemzés alkalmazása a külföldi népességcsoportok területi elhelyezkedésének vizsgálatára}

Jelen elemzésünkben a Magyarországon élö legjelentősebb kủlföldi népességcsoportok (Románia, Szerbia, Szlovákia, EU15, Ukrajna) területi elhelyezkedésének okait vizsgáltuk meg. Mint láttuk, a szakirodalom általában a megélhetést, a fizetések különbségeit emeli ki, de jelentős szerepet kap a települések elhelyezkedése is, s ezt a földrajzi faktort fogjuk körüljárni kicsit részletesebben.

Vizsgálatunkban útmodell segítségével a külföldiek kistérségenkénti, 2001 és 2008 közötti átlagos arányát igyekeztünk tényezőkre bontva megvizsgálni. Elemzésünkben elsôsorban arra törekedtünk, hogy a kistérségek közúti elérhetőségi viszonyainak és a bevándorlók arányának összefüggését feltárjuk.

$\mathrm{Az}$ útmodellekben a független változók és a függő változó közötti nulladrendủ lineáris korrelációt bontjuk két részre. Az egyik rész az a hatás, amelyet a független változóink közvetlenül fejtenek ki a függő változóra, a másik rész pedig az a hatás, amelyet a független változók más, közbülső változókon keresztül gyakorolnak (Székhelyi-Barna 2008).

$\mathrm{Az}$ útelemzés nem más, mint egymásra épuilö többváltozós lineáris regressziós becslések (OLS-ek) sorozata. Első lépésben megnézzük, hogy az elsődleges változók együttesen hogy hatnak a másodlagos csoporthoz tartozó indikátorokra; ez annyi regresszió, ahány másodlagos változó van. Második lépésben megnézzük, hogy az elsődleges és a másodlagos változók együttesen hogy hatnak a harmadlagosakra. Végül egy olyan regressziót futattunk, ahol az összes változó együtt szerepel. A szignifikáns indikátorok hatását a felderített utakkal együtt elemezzük (Németh 2008). 
Tóth Géza - Kincses Áron : A hazánkba bevándorlók területi elhelyezkedésének vizsgálata.

Tér és Társadalom 23. évf. 2009/4. 61-81. p.

66 Tóth Géza-Kincses Áron

TÉT XXIII. évf. 2009 — 4

Elemzésünkben a következő mutatókat használtuk:

- Elérhetőség

- A kistérségközpontok közúti távolsága a legközelebbi „megfelelő” határátkelötől, percben (HATAR)

- A kistérségközpontok közúti távolsága Budapesttöl, percben (ELBP)

- Gazdasági helyzet

- Személygépkocsik ezer állandó lakosra jutó számának átlaga, 2000-2007 (SZGK)

- Élelmiszer jellegủ üzletek és áruházak 1000 állandó lakosra jutó számának átlaga, 2000-2007 (ELEL)

- Egy adózóra jutó jövedelem átlaga, 2000-2007 (JOVA)

- 1000 lakosra jutó müködő vállalkozások számának átlaga, 2000-2006 (VALL)

- Társadalmi helyzet

- Természetes szaporodás/fogyás 1000 lakosra, 2000-2007 (FOGY)

- 1000 lakosra jutó vándorlási egyenleg, 2000-2007 (VAND)

- Ismertté vált közvádas bủncselekmények 1000 lakosra jutó számának átlaga, 2001-2007 (BUNC)

- Közép- és felsőfokú végzettséggel rendelkezök aránya a lakónépességből, $\%, 2001$ (FPFE)

- A migránsok korábbi területi elhelyezkedése

- Az adott országból érkező migránsok lakónépességhez viszonyított aránya, 2000 (ARANY)

Ezeket az értékeket tekintettük független változóknak, amelyek a függỏ változót alkotó kistérségi adott állampolgárságú külföldiek arányát magyarázzák.

A migránsok területi elhelyezkedésével kapcsolatban tehát összességében négy változócsoportot állítottunk össze. $\mathrm{Az}$ egyes változócsoportokban vizsgálataink során több mutató is szerepelt, melyek az előzetes számítások eredményeként kerültek ki a rendszerünkböl.

Az egyes változócsoportokkal kapcsolatban a következő hipotéziseket tettük.

Elérhetôség: minél közelebb fekszik az adott kistérség Budapesthez, illetve a megfelelő határszakaszhoz, annál magasabb a külföldiek aránya.

Gazdasági helyzet: minél kedvezőbb egy-egy kistérség gazdasági ereje, annál nagyobb a külföldiek aránya.

Társadalmi helyzet: minél kedvezőbb a demográfiai helyzete és magasabb a népesség végzettsége, illetve alacsonyabb a bünözés, annál magasabb a külföldiek aránya a kistérségben.

A migránsok korábbi területi elhelyezkedése: minél nagyobb volt a migránsok aránya korábban, annál nagyobb lesz a vizsgált időszakban is. 
Tóth Géza - Kincses Áron : A hazánkba bevándorlók területi elhelyezkedésének vizsgálata. Tér és Társadalom 23. évf. 2009/4. 61-81. p.

TÉT XXIII. évf. 2009 घ 4

A hazánkba bevándorlók ...

Feltételezéseink szerint az elsődleges magyarázó tényezők (elérhetőség) befolyásolják a másodlagos tényezők különbségeit, melyeket részletesen feltár Hardi Tamás a témáról szóló cikkében (Hardi 2008) (gazdasági helyzet, társadalmi helyzet), melyek viszont hatással vannak a harmadlagos tényezỏre (a migránsok korábbi területi elhelyezkedése). Feltételezzük azt is, hogy az elsödleges és másodlagos magyarázó tényezók a migránsok arányára nemcsak közvetetten (a harmadlagosakon „keresztül"), de önállóan is hatnak.

Az útelemzés kezdő lépéseként, egyszerü többváltozós lineáris regresszióval az összes független változóval egyszerre, kistérségi adatok alapján igyekeztünk fóbb állampolgárságok szerint megmagyarázni a külföldiek arányait. Eredményeinket a 3. táblázat foglalja össze. Ebböl egyrészt megállapíthatjuk, hogy a vizsgálatba bevont változóink együttesen 0,83 és 0,99 közötti $R^{2}$ értékkel magyarázzák a megfelelö állampolgárságú külföldi lakosság lakónépességen belüli arányát, másrészt állampolgárságok szerint jelentỏs eltéréseket találunk a magyarázó változók súlyában. Harmadrészt leszögezhetjük, hogy a legjelentősebb magyarázó ereje minden esetben a régebben érkezett migránsok kistérségenkénti arányának van. Azaz, az újonnan érkezők a már meglévő struktúra szerint oszlanak meg.

3. TÁBLÁZAT
Regressziós eredmények
(Regression Results)

\begin{tabular}{clccccc}
\hline $\begin{array}{c}\text { Függö } \\
\text { változó }\end{array}$ & Megnevezés & EU15 & Szerbia & Románia & Szlovákia & Ukrajna \\
\hline$\beta_{1}$ & HATAR & $-0,212$ & $-0,014$ & 0,006 & $-0,123$ & $-0,022$ \\
$\beta_{2}$ & ELBP & 0,034 & 0,008 & $-0,065$ & 0,016 & 0,016 \\
$\beta_{3}$ & SZGK & $-0,058$ & 0,039 & 0,170 & 0,100 & 0,023 \\
$\beta_{4}$ & ELEL & 0,077 & $-0,017$ & $-0,023$ & 0,044 & 0,027 \\
$\beta_{5}$ & JOVA & $-0,413$ & 0,006 & 0,051 & 0,032 & 0,053 \\
$\beta_{6}$ & VALL & $-0,096$ & $-0,016$ & $-0,138$ & $-0,182$ & 0,025 \\
$\beta_{7}$ & FOGY & 0,006 & 0,001 & 0,038 & $-0,014$ & $-0,001$ \\
$\beta_{8}$ & VAND & 0,150 & 0,007 & 0,044 & $-0,031$ & 0,004 \\
$\beta_{9}$ & BUNC & $-0,016$ & $-0,003$ & $-0,015$ & 0,086 & $-0,018$ \\
$\beta_{10}$ & KPFE & 0,215 & $-0,022$ & $-0,059$ & 0,095 & $-0,016$ \\
$\beta_{11}$ & ARANY & 0,838 & 0,983 & 0,863 & 0,817 & 0,971 \\
$\mathrm{R}^{2}$ & & 0,830 & 0,990 & 0,920 & 0,820 & 0,960 \\
\hline
\end{tabular}

Forrás: Saját számítás.

Az útelemzés segítségével azonban csak a kistérségek földrajzi elhelyezkedésével (megfelelő határtól és Budapesttől való távolság) igyekszünk megmagyarázni a külföldiek arányát, kimutatni a földrajzi helyzet szerepének nagyságát. Az elhelyezkedés közvetlenül és a többi változón keresztül közvetetten is kifejtheti hatását, melyet számszerủsíteni is fogunk. Mivel két független, elsődleges változónk van, így a kétváltozós lineáris regressziók $\beta$-it bontja fel az eljárás additív módon közvetett és közvetlen részekre. Útelemzésünk sematikus rendszerét a 2. ábra szemlélteti. 
Tóth Géza - Kincses Áron : A hazánkba bevándorlók területi elhelyezkedésének vizsgálata.

Tér és Társadalom 23. évf. 2009/4. 61-81. p.

68 Tóth Géza-Kincses Áron

TÉT XXIII. évf. 2009

\section{2. ÁBRA}

A magyarázó változók csoportjainak oksági viszonyrendszere (Causality Relations of the Groups of Explanatory Variables)

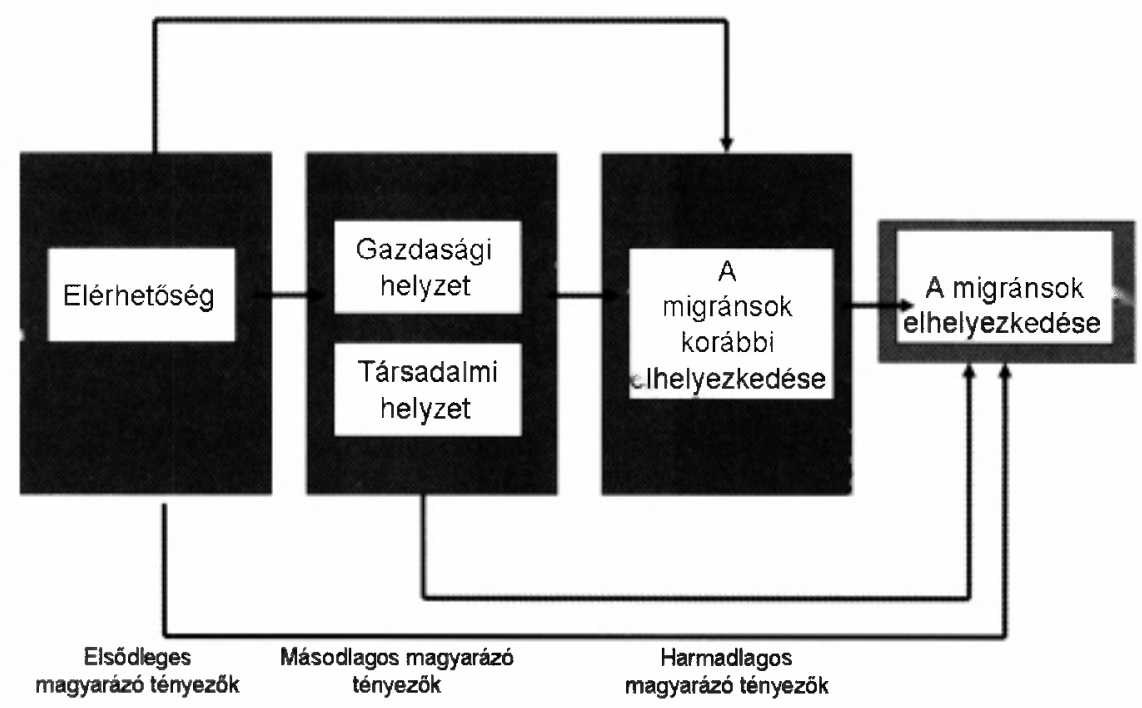

Forrás: Saját szerkesztés.

Következő lépésként az elérhetöség és a migráns csoportok lakónépességhez képesti arányai közötti kapcsolatokat vizsgáljuk kistérségi szinten, kezdetben függetlenül azok közvetett vagy közvetlen szerepétöl.

A 4. táblázat az „egyszerü” kétváltozós regresszió meredekségeit szemlélteti, az. $R$ pedig ennek a sztochasztikus viszonynak az erösségét méri. Az $R^{2}$ mutatja meg, hogy a földrajzi helyzet mekkora százalékban magyarázza a megfeleló állampolgárságú külföldiek kistérségi eloszlásának szóródását. Így számszerúsíteni tudjuk, hogy a földrajzi elhelyezkedés önmagában 22-30\%-ban megmagyarázza a vizsgált állampolgárságú külföldiek kistérségi varianciáját, tehát a külföldiek magyarországi lakóhely választásában jelentős szerep jut a földrajzi helyzetnek. A korrektség okán meg kell jegyeznünk, hogy a 3. táblázat alapján ennél is nagyobb a szerepe a külföldiek tudatos lakóhely választásának. Hiszen nagy valószínüség szerint azokban a kistérségekben telepednek le, ahol honfitársaik már nagyobb számban élnek, segítve öket a vándorlás folyamatában, a beilleszkedésben, az adminisztratív tevékenységek megoldásában, a munkahely keresésében, a lakhatás kérdésében.

A 4. táblázat megfogalmazásában a legközelebbi megfelelő határ az EU15 országok vizsgálata során az osztrák határ, míg a többi esetben az állampolgárságoknak megfelelő határok. Ha a regresszióban ezekhez a változókhoz tartozó meredekségek negatívak, az azt jelenti, hogy átlagosan a határtól távolodva csökken a vizsgált külföldi állampolgárságú csoport aránya, ha pozitív, akkor pedig növekszik. Hasonlóan, ha a Budapest elérési idejéhez tartozó béták negatívak, akkor a fővárostól 
Tóth Géza - Kincses Áron : A hazánkba bevándorlók területi elhelyezkedésének vizsgálata. Tér és Társadalom 23. évf. 2009/4. 61-81. p.

TÉT XXIII. évf. 2009 - 4

A hazánkba bevándorlók ...

69

távolodva átlagosan csökken a külföldiek lakónépességen belüli aránya, pozitív meredekségek esetén viszont nö. Mint a 4. táblázat adatain is látható - a Romániából bevándorlók kivételével -, valamennyi esetben a határátkelőktől mért távolság szerepe jelentősebb, mint a Budapesttől mért távolságé, melyet a standardizált $\beta$-k közötti különbség mutat. Azaz a föváros centrum jellege mellett a határoknak is jelentős szerepe van a migráció földrajzában.

\section{TÁBLÁZAT}

Kétváltozós regressziós eredmények az elérhetöségek és a migránsok arányai között (Binary Regression Results between Availabilities and Migrants' Proportions)

\begin{tabular}{|c|c|c|}
\hline $\begin{array}{l}\text { Állampolgárok népes- } \\
\text { ségen belüli arányai }\end{array}$ & $\begin{array}{c}\text { Legközelebbi megfeleló } \\
\text { határátkelőhely elérési } \\
\text { ideje, } 2008\end{array}$ & $\begin{array}{c}\text { Budapest elérési } \\
\text { ideje, } 2008\end{array}$ \\
\hline \multicolumn{3}{|c|}{ EU15 } \\
\hline$\beta$ & $-0,509$ & 0,141 \\
\hline $\mathbf{R}^{2}$ & \multicolumn{2}{|c|}{0,221} \\
\hline \multicolumn{3}{|c|}{ Románia } \\
\hline $\mathbf{R}^{2}$ & \multicolumn{2}{|c|}{0,259} \\
\hline \multicolumn{3}{|c|}{ Szerbia } \\
\hline $\mathbf{R}^{2}$ & \multicolumn{2}{|c|}{0,284} \\
\hline \multicolumn{3}{|c|}{ Szlovákia } \\
\hline $\mathbf{R}^{2}$ & \multicolumn{2}{|c|}{0,236} \\
\hline \multicolumn{3}{|c|}{ Ukrajna } \\
\hline $\mathbf{R}^{2}$ & $-0,489$ & 0,228 \\
\hline
\end{tabular}

Forrás: Saját számítás.

$\mathrm{Az}$ útelemzés további részében a $\beta$ értékeket bontjuk fel közvetlen és közvetett utakra. Ehhez először azt vizsgáljuk, hogy az elsődleges tényezők (elérhetőség) közül melyek és miként befolyásolják a másodlagosakat (gazdasági helyzet, társadalmi helyzet). A határtól mért távolságokkal kezdjük az elemzésüinket:

Az osztrák határtól mért távolság - a közvádas büncselekményeken kívül - valamennyi vizsgált másodlagos tényezöre szignifikáns hatással van (a 3-7. ábrák esetén a nem szignifikáns értékeket nem jelöltük). Az elöjel legtöbb esetben negatív, tehát a határhoz közelebb nagyobb a fejlettség, jobb az ellátottság, iskolázottság stb. Pozitív előjel csak a természetes szaporodásnál/fogyásnál figyelhető meg, mely hazánk jelenlegi demográfiai folyamataival összhangban van. A legerősebb kapcsolatot a személygépkocsival való ellátottság és az osztrák határtól való távolság vonatkozásában láthatjuk (3. ábra). 
Tóth Géza - Kincses Áron : A hazánkba bevándorlók területi elhelyezkedésének vizsgálata.

Tér és Társadalom 23. évf. 2009/4. 61-81. p.

70 Tóth Géza-Kincses Áron

TÉT XXIII. évf. 2009 『 4

\section{3. ÁBRA}

Az osztrák határtól mért távolság szerepe az EU15 országaiból 2001-2008 között bevándorlók népességhez viszonyított arányának magyarázatában (The Role of Distance from the Austrian Border in Explaining the Ratio of Immigrants from EU-15 Countries in 2001-2008 to Total Population)

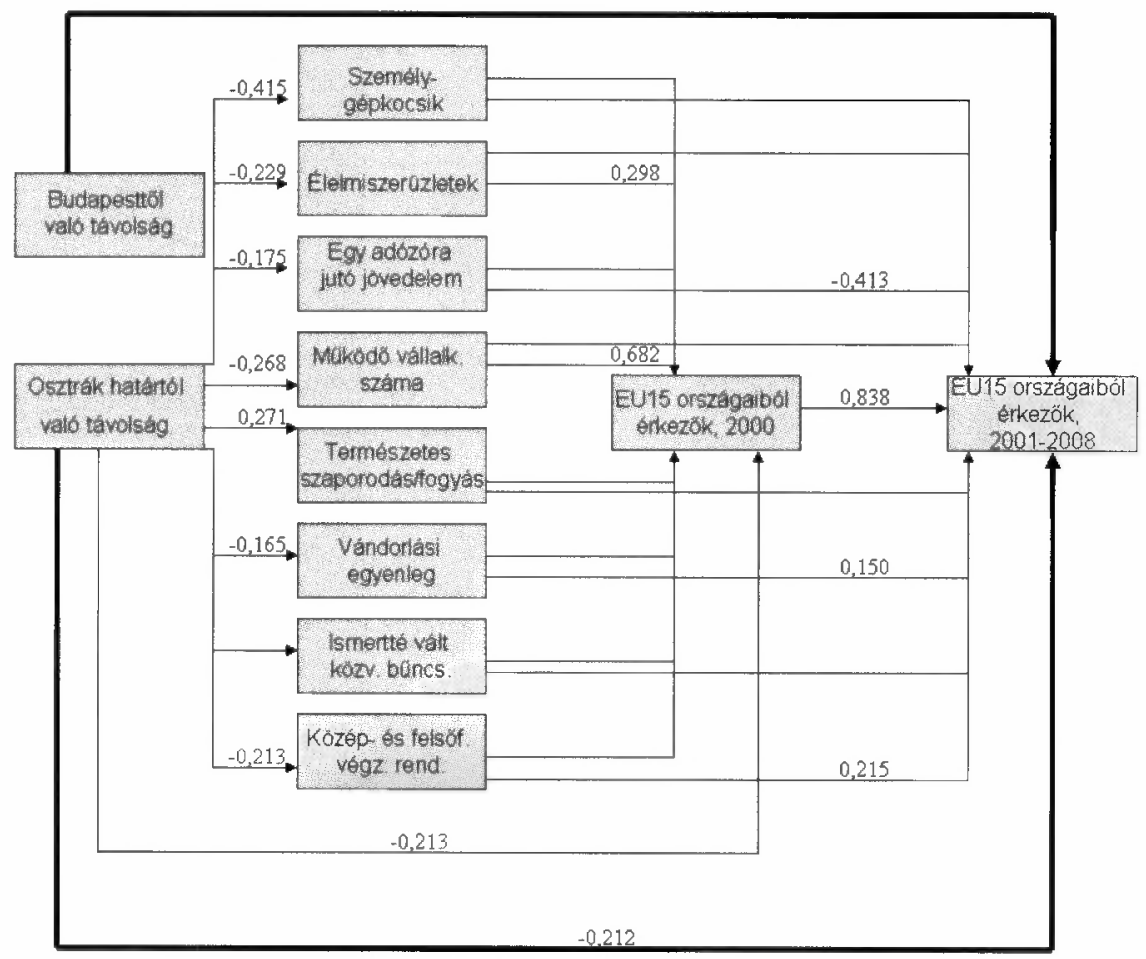

Forrás: Saját szerkesztés.

A román határtól mért távolság a vándorlási egyenleg, a büncselekmények és a végzettség vonatkozásában inszignifikáns, s a többi másodlagos mutató tekintetében is más hatással bír, mint azt az előzőekben láthattuk (4. ábra). Az osztrák határtól mért távolsággal ellentétben az elöjelek itt zömében pozitívak, vagyis a társadalmi-gazdasági helyzet a határtól távolodva javul, a határ egyértelmủen perifériaként fogható fel. A határtól mért távolság ebben a vonatkozásban a gépjármüsürüséggel van a legszorosabb kapcsolatban. Azonban a természetes szaporodás a határtól távolodva csökken.

A szerb határtól mért távolság csak három másodlagos mutatóra gyakorol szignifikáns hatást (5. ábra). A határtól távolodva javul az élelmiszeriuzletekkel való ellátottság, az egy adózóra jutó jövedelem és a természetes szaporodás. 
Tóth Géza - Kincses Áron : A hazánkba bevándorlók területi elhelyezkedésének vizsgálata. Tér és Társadalom 23. évf. 2009/4. 61-81. p.

TÉT XXIII. évf. 2009 - 4

A hazánkba bevándorlók ...

71

\section{4. ÁBRA}

A román határtól mért távolság szerepe a Romániából 2001-2008 között bevándorlók népességhez viszonyított arányának magyarázatában

(The Role of Distance from the Romanian Border in Explaining the Ratio of Immigrants from Romania in 2001-2008 to Total Population)

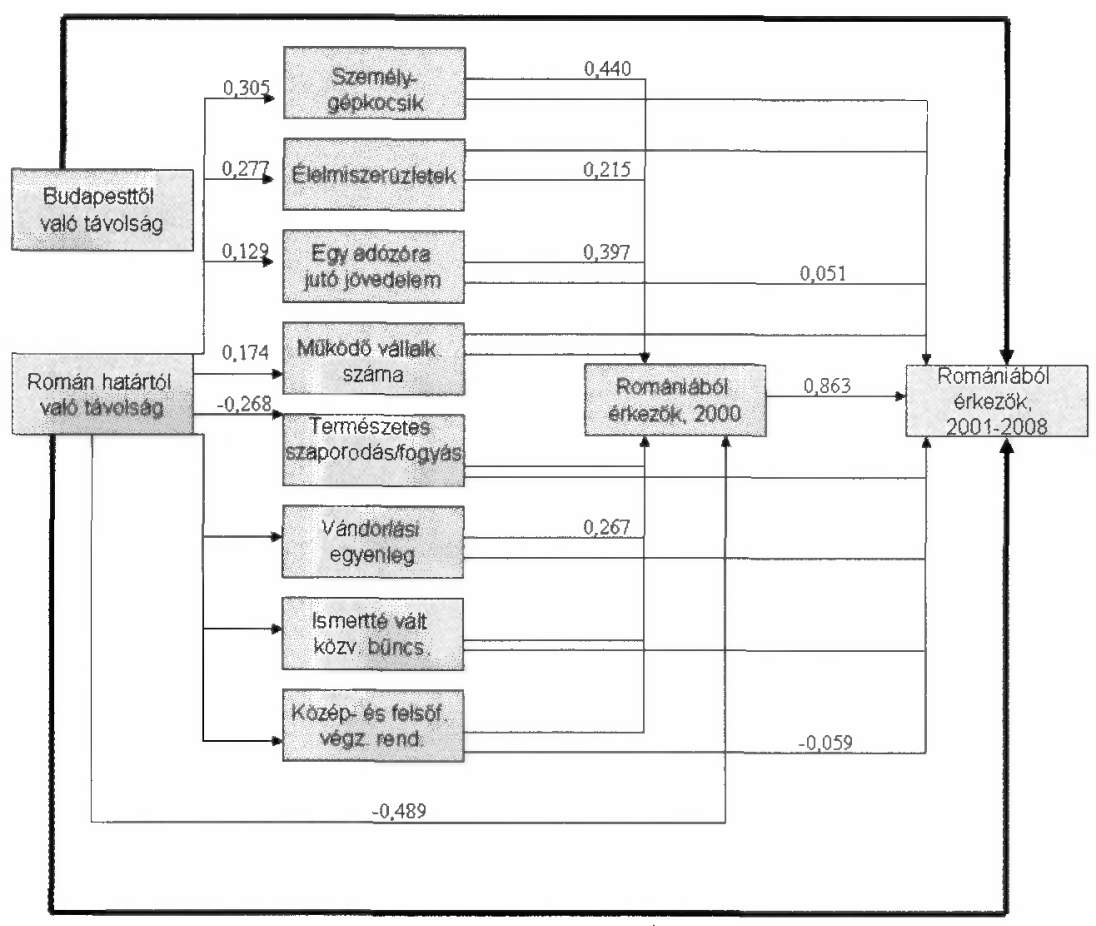

Forrás: Saját szerkesztés.

A szlovák határtól mért távolság a személygépkocsi ellátottságra, az egy adózóra jutó jövedelemre, a vállalkozássürúségre és a természetes szaporodásra hat szignifikánsan (6. ábra). E határtól távolodva nỏ a gépjármủ-, illetve vállalkozássürüség, csökken a termelékenység és a természetes szaporodás.

Végül az ukrán határtól mért távolság szintén 3 másodlagos változóra gyakorol szignifikáns hatást (7. ábra). A gépjármủ és a vállalkozássürüség a határtól távolodva növekszik, illetve a természetes szaporodás csökken. A határtól mért távolság ez utóbbi mutatóra a legerósebb. A szerb, szlovák és ukrán határtól mért távolság a természetes szaporodással volt a legszorosabb kapcsolatban. 
Tóth Géza - Kincses Áron : A hazánkba bevándorlók területi elhelyezkedésének vizsgálata.

Tér és Társadalom 23. évf. 2009/4. 61-81. p.

72 Tóth Géza-Kincses Áron

TÉT XXIII. évf. 2009

\section{5. ÁBRA}

A szerb határtól mért távolság szerepe a Szerbiából 2001-2008 között bevándorlók népességhez viszonyitott arányának magyarázatában

(The Role of Distance from the Serbian Border in Explaining the Ratio of Immigrants from Serbia in 2001-2008 to Total Population)

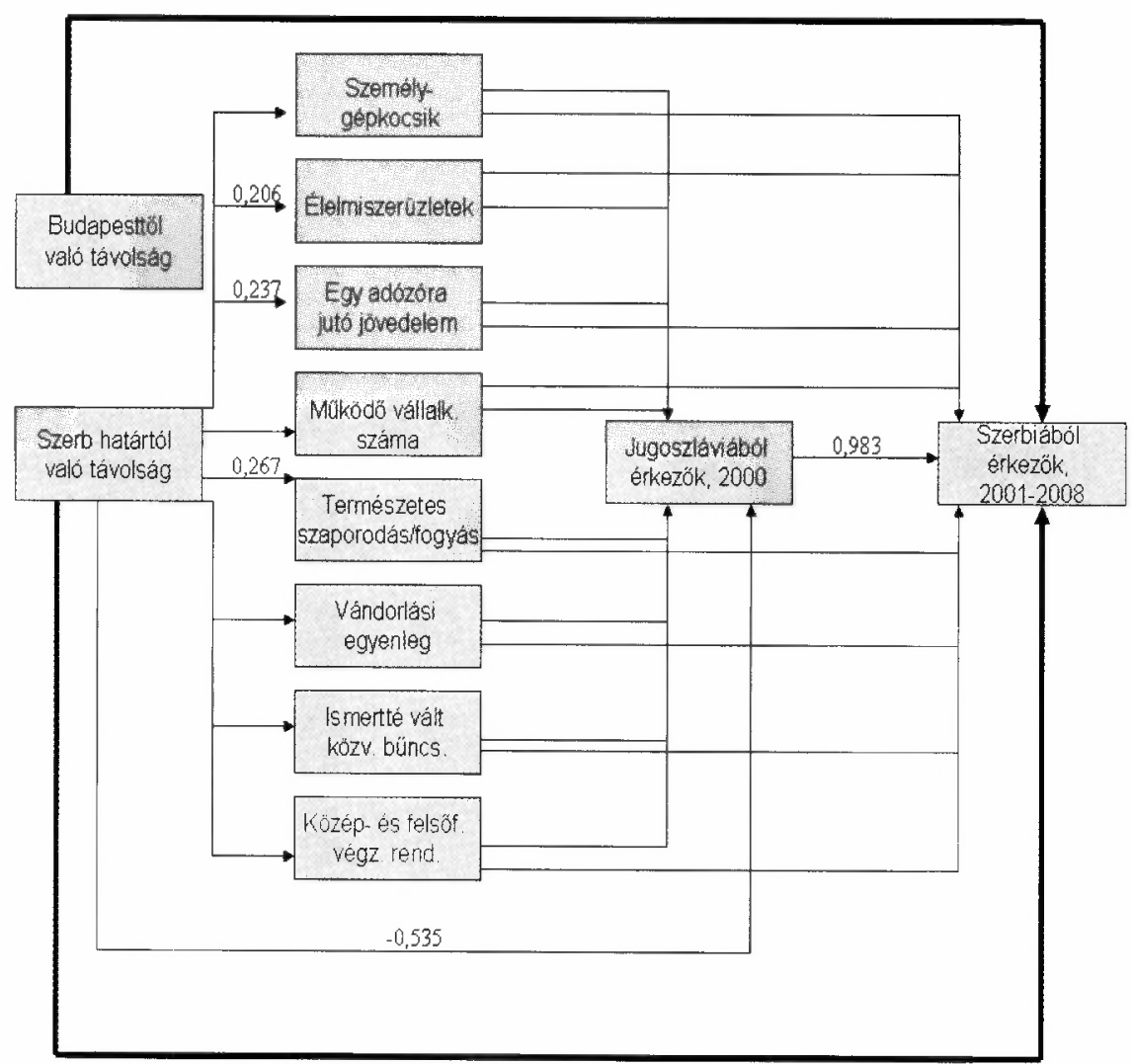

Forrás: Saját szerkesztés.

Az elsődleges és a másodlagos mutatók közötti kapcsolat szorossága a determinációs együttható segítségével megvizsgálható, azaz, hogy az elérhetőségi mutatók mennyiben magyarázzák a társadalmi-gazdasági mutatók átlagtól való eltérését. Megállapíthatjuk, hogy az egyenlötlenségi mutatók elsősorban a vándorlási egyenleg, a gépjármủellátottság és a termelékenység szóródását magyarázzák (mindhárom esetében a szóródás több mint egyharmadát értelmezi az elérhetőség). Ezzel szemben a büncselekményeknél a súlyozott determinciós együttható csak 5\%, mely a vizsgált mutatók közül a legalacsonyabb.

Miután megvizsgáltuk az elsődleges és másodlagos magyarázó tényezők kapcsolatát, figyelmünket fordítsuk arra, hogy ezek a változók milyen hatással vannak a harmadlagos változókra. 
Tóth Géza - Kincses Áron : A hazánkba bevándorlók területi elhelyezkedésének vizsgálata. Tér és Társadalom 23. évf. 2009/4. 61-81. p.

TÉT XXIII. évf. 2009 - 4

A hazánkba bevándorlók... 73

\section{6. ÁBRA}

A szlovák határtól mért távolság szerepe a Szlovákiából 2001-2008 között bevándorlók népességhez viszonyított arányának magyarázatában (The Role of Distance from the Slovak Border in Explaining the Ratio of Immigrants from Slovakia in 2001-2008 to Total Population)

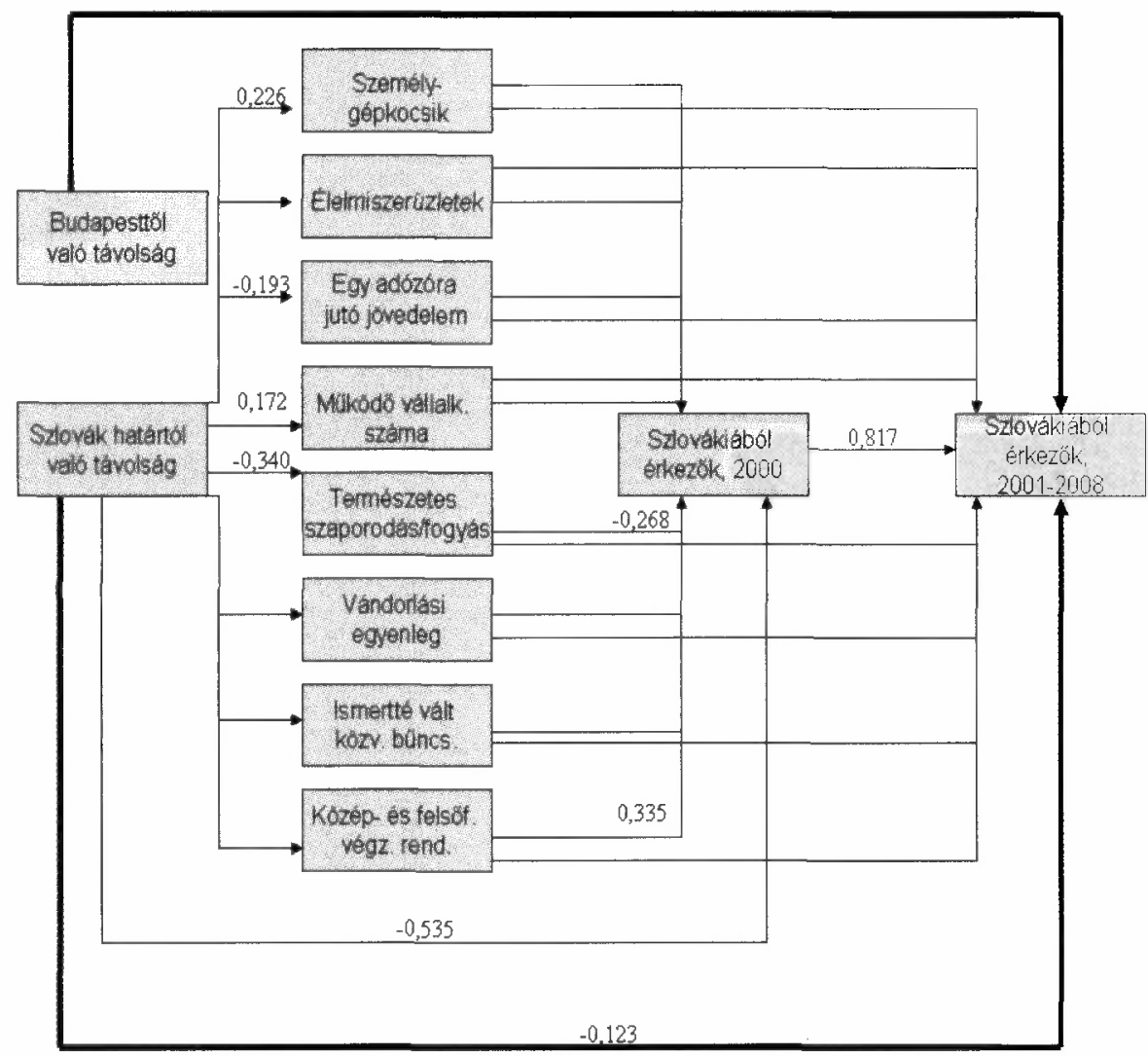

Forrás: Saját szerkesztés.

2000-ben az EU15 országaiból érkezettek lakónépességhez viszonyított arányára egyrészt közvetlenül hat az osztrák határtól mért távolság, illetve ugyanennek a hatásai az élelmiszerüzletek fajlagos adatán és a vállalkozássürüségen keresztül. E három útvonal közül a közvetlen a legerősebb. Az előjel ebben az esetben negatív, vagyis már a 2000-es évet tekintve is csökkent az EU15 országaiból érkezők aránya a határtól távolodva.

A Romániából 2000-ben érkezők arányára egyrészt közvetlenül szignifikáns hatással bír a román határtól mért távolság, valamint ennek hatása érezhetô még a gépjármú és élelmiszerüzlet ellátottságon és a termelékenységen keresztül is. A vizsgált utak közül a határtól való távolság közvetlen hatása a legerősebb és negatív előjelü, vagyis a távolság növekedésével a Romániából érkezők aránya már 2000-ben is csökkent. 
Tóth Géza - Kincses Áron : A hazánkba bevándorlók területi elhelyezkedésének vizsgálata. Tér és Társadalom 23. évf. 2009/4. 61-81. p.

74 Tóth Géza-Kincses Áron

TÉT XXIII. évf. 2009

\section{7. ÁBRA}

Az ukrán határtól mért távolság szerepe az Ukrajnából 2001-2008 között bevándorlók népességhez viszonyított arányának magyarázatában (The Role of Distance from the Ukrainian Border in Explaining the Ratio of Immigrants from the Ukraine in 2001-2008 to Total Population)

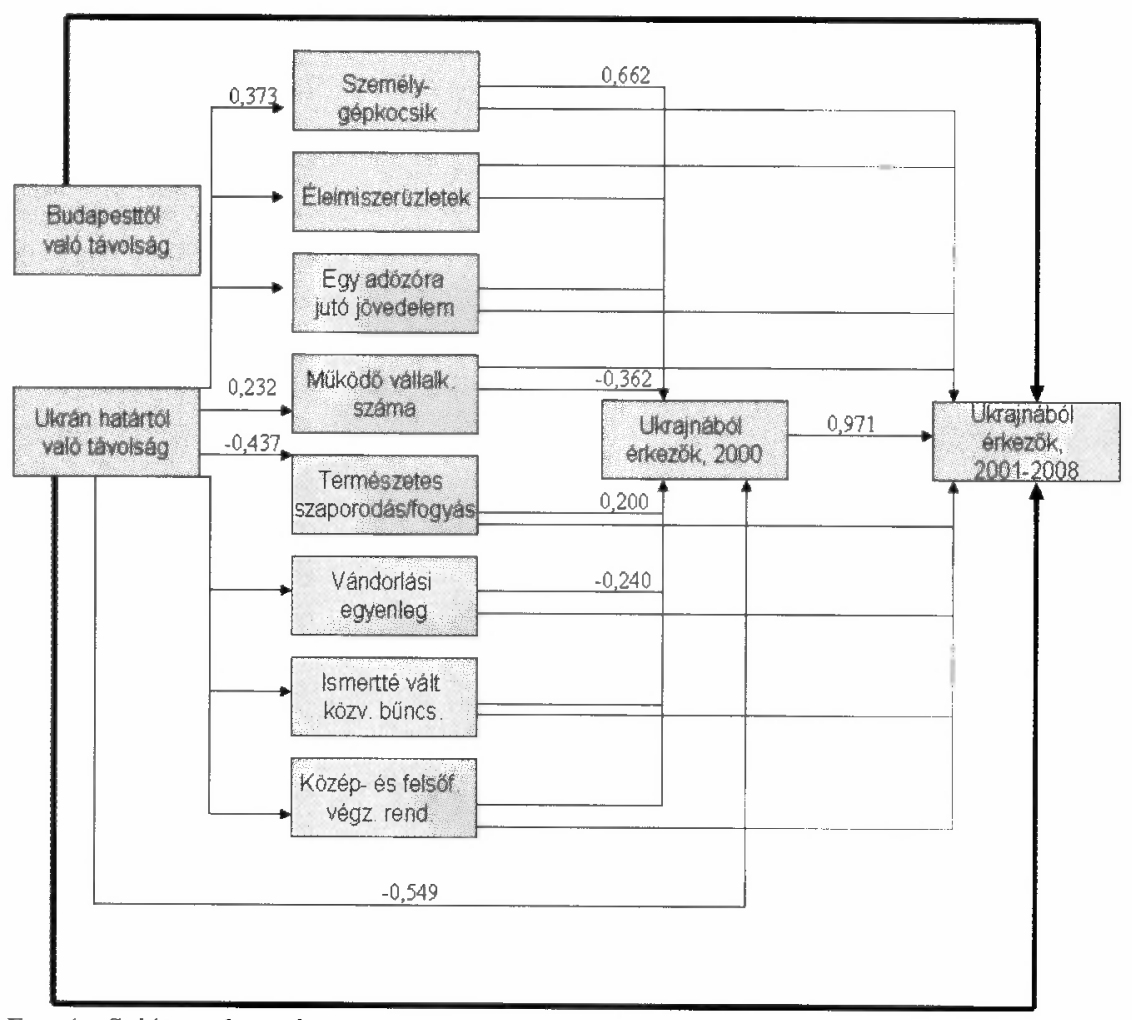

Forrás: Sajât szerkesztés.

A Jugoszláviából 2000-ben érkezők arányára csak a szerb határtól való távolság hat szignifikánsan, a másodlagos tényezőkön keresztül nincs szignifikáns kapcsolat. A határtól mért távolság növekedésével a migránsok aránya csökken.

A Szlovákiából 2000-ben érkezők arányára egyrészt közvetlenül hat a határtól mért távolság, másrészt pedig a természetes szaporodáson/fogyáson keresztül. A két jelzett útvonal közül a közvetlen bír jelentősebb erővel, $s$ előjele ennek is negatív, vagyis a távolság növekedésével itt is csökken a bevándorlók aránya.

Végül az ukrán határtól mért távolságnak közvetlen szignifikáns hatása van az Ukrajnából 2000-ben betelepülők lakossághoz viszonyított arányára (a közvetlen hatás valamennyi határszakaszt figyelembe véve itt a legerősebb), illetve a hatás közvetetten érezhető a gépjármü-, illetve vállalkozássúrüségen és a természetes szaporodáson/fogyáson keresztül. 
Tóth Géza - Kincses Áron : A hazánkba bevándorlók területi elhelyezkedésének vizsgálata. Tér és Társadalom 23. évf. 2009/4. 61-81. p.

A harmadlagos változóknak a függỏ változókra gyakorolt hatását tekintve megállapítható, hogy ez valamennyi esetben szignifikáns, s a legerősebb standardizált $\beta$-együtthatót mutatja. Vagyis a bevándorlók arányát leginkább befolyásoló tényező modellünk alapján a korábbi bevándorlók területi elhelyezkedése. A legmagasabb standardizált $\beta$-együtthatót a Szerbiából bevándoroltaknál figyelhetjük meg.

A teljes modellt tekintve, a határtól való távolság közvetlenül a bevándorlók 2001 és 2008 közötti átlagos arányára csak az EU15 és a Szlovákiából bevándorlók esetében bír szignifikáns hatással. Nem mondható viszont ez el a Budapesttől mért távolságra, az ugyanis közvetlen hatásait tekintve egyik esetben sem szignifikáns. Ez természetesen nem jelenti azt, hogy a Budapesttől mért távolság nincs hatással a bevándorlók lakónépességhez viszonyított arányára. Annak hatása viszont nem közvetlenül, hanem inkább csak a társadalmi-gazdasági tényezókön keresztül érvényesüil. Így a cikkünkben külön nem részletezzük útelemzésünknek ezt a részét, de a későbbi eredményeink miatt ezeket a számításokat is feltüntettük a 3-7. ábrákon.

A modellünk ,út-erősségének" feltárása után rátérünk az elérhetőségek migránsok elhelyezkedésére gyakorolt tényleges hatásainak feltárására. Kérdés, hogy az egyes állampolgárságok szerinti bevándorlók arányára az elérhetóségi mutatók szerepe közvetlenül vagy csak más tényezőkön keresztül, közvetve érvényesül-e.

Tekintsük az osztrák határtól mért távolság változóját. Amint a 3. ábrából láthatjuk, ennek az elsődleges változónak a közvetlen hatása -0,2123. A közvetett utak pedig egyrészt végigmehetnek az elsódleges, másodlagos és harmadlagos változókon, ekkor a kiindulástól a függő változóig lévő összes utat őssze kell adni, a megfelelő útrészeket pedig össze kell szorozni, azaz (a szignifikanciáktól most eltekintve): $(-0,4148 *-0,1847 * 0,838)+(-0,2291 * 0,2976 * 0,838)+(-0,1749 * 0,0324 * 0,838)+$ $(-0,268 * 0,6817 * 0,838)+(0,2714 *-0,0822 * 0,838)+(-0,1653 * 0,0435 * 0,838)+$ $(-0,027 * 0,1306 * 0,838)+(-0,2125 *-0,1349 * 0,838)=-0,15463$.

Továbbá az elsődleges és másodlagos változókon keresztül: $(-0,4148 *-0,058)+(-0,2291 * 0,07725)+(-0,1749 *-0,413)+(-0,2682 *-0,0958)+$ $(0,2714 * 0,00642)+(-0,1653 * 0,1496)+(-0,027 *-0,0163)+(-$ $0,2125 * 0,21524)=0,03599$.

Vagy az elsődleges és harmadlagos változókon keresztül: $-0,2126 * 0,838=-0,1782$. Így a közvetett hatások összesen: $-0,15463+0,03599+-0,1782=-0,2968$. A kỏzvetlen hatásokkal együtt: -0,2968+-0,2123=-0,5092. Azaz megkaptuk az öszszes útból a 4. táblázatban szereplő megfelelő parciális meredekséget.

A vizsgált állampolgárságokra, mindkét elérhetóségi mutatóra kiszámoltuk az összes utat. Eredményeinket az 5. táblázat tartalmazza.

Általánosan megállapítható, hogy az elérhetőségi mutatók hatása valamennyi esetben nem közvetlenül, hanem elsösorban a társadalmi-gazdasági helyzetet leíró mutatókon keresztül, közvetetten érhető tetten. 
Tóth Géza - Kincses Áron : A hazánkba bevándorlók területi elhelyezkedésének vizsgálata.

Tér és Társadalom 23. évf. 2009/4. 61-81. p.

76 Tóth Géza-Kincses Áron

TÉT XXIII. évf. 2009 — 4

\section{TÁBLÁZAT}

A közvetlen és közvetett utak szerepe a bevándorlók népességen belüli arányának magyarázatában (standardizált $\beta$-együtthatók)

(The Role of Direct and Indirect Paths in Explaining the Share of Immigrants

in Total Population [standardised $\beta$ coefficients])

\begin{tabular}{|c|c|c|}
\hline $\begin{array}{c}\text { Állampolgárok } \\
\text { népességen belüli } \\
\text { arányai }\end{array}$ & $\begin{array}{c}\text { Legközelebbi megfelelö } \\
\text { határátkelöhely elérési } \\
\text { ideje, } 2008\end{array}$ & $\begin{array}{c}\text { Budapest elérési ideje, } \\
2008\end{array}$ \\
\hline \multicolumn{3}{|c|}{ EU15 } \\
\hline közvetett & $-0,297$ & 0,106 \\
\hline közvetlen & $-0,212$ & 0,034 \\
\hline összesen & $-0,509$ & 0,141 \\
\hline $\mathrm{R}^{2}$ & \multicolumn{2}{|c|}{0,221} \\
\hline \multicolumn{3}{|c|}{ Románia } \\
\hline közvetett & $-0,199$ & $-0,424$ \\
\hline közvetlen & 0,006 & $-0,065$ \\
\hline összesen & $-0,193$ & $-0,488$ \\
\hline $\mathrm{R}^{2}$ & \multicolumn{2}{|c|}{0,259} \\
\hline \multicolumn{3}{|c|}{ Szerbia } \\
\hline közvetett & $-0,562$ & 0,195 \\
\hline közvetlen & $-0,014$ & 0,008 \\
\hline összesen & $-0,575$ & 0,203 \\
\hline $\mathrm{R}^{2}$ & \multicolumn{2}{|c|}{0,284} \\
\hline \multicolumn{3}{|c|}{ Szlovákia } \\
\hline közvetett & $-0,393$ & 0,060 \\
\hline közvetlen & $-0,123$ & 0,016 \\
\hline összesen & $-0,516$ & 0,076 \\
\hline $\mathbf{R}^{2}$ & \multicolumn{2}{|c|}{0,236} \\
\hline \multicolumn{3}{|c|}{ Ukrajna } \\
\hline közvetett & $-0,467$ & 0,212 \\
\hline közvetlen & $-0,022$ & 0,016 \\
\hline összesen & $-0,489$ & 0,228 \\
\hline $\mathbf{R}^{2}$ & \multicolumn{2}{|c|}{0,303} \\
\hline
\end{tabular}

Forrás: Saját számítás.

\section{A külföldiek magyarországi elhelyezkedésének vizsgálata helyzetpotenciál mutató segítségével}

Mint láttuk, az adott kiilföldi állampolgár számára az ugyanolyan állampolgárságú, Magyarországon élő honfitársai jelentenek vonzó célpontot. Így a helyzetpotenciál mutató segítségével képet kaphatunk arról, hogy a különbözỏ állampolgárságú külföldiek hogyan látják hazánk területét, mint potenciális letelepedési célpontokat. 
Tóth Géza - Kincses Áron : A hazánkba bevándorlók területi elhelyezkedésének vizsgálata. Tér és Társadalom 23. évf. 2009/4. 61-81. p.

TÉT XXIII. évf. 2009 - 4 A hazánkba bevándorlók... 77

A használt elérhetôségi potenciált a Hansen-féle gravitációs modellből számoltunk (Hansen 1959).

A kutatás során az általunk korábban bemutatott módon a gravitációs analógián alapuló modellt számítottuk lineáris ellenállási tényezővel (Tóth-Kincses 2007). Az elérhetỏ célok tömegeit az egyes kistérségek megfelelő állampolgárságú külföldi népessége alapján állapítottuk meg. Jelen elemzésben figyelembe vettük az adott térségen beluili elérhetóségi viszonyokat is, vagyis a térségen belüli elérhető célokat. Modellünk alapján tehát a tér egy i pontjában a potenciál:

$P_{i}=\sum_{j \neq i} \frac{B_{j}}{d_{i j}}+\frac{B_{i}}{d_{i}}$ ahol: $\mathrm{B}_{\mathrm{i}}, \mathrm{B}_{\mathrm{j}}$ az elérhetö célok tömegei, $\mathrm{d}_{\mathrm{ij}}$ az $\mathrm{i}$ és $\mathrm{j}$ kistérség-

központok közötti távolság percben, míg $\mathrm{d}_{\mathrm{i}}$ a saját távolság (percekben), amit úgy számolhatunk ki, hogy az adott kistérség területét körnek tekintve meghatározzuk annak sugarát, melyet arányosnak tekintünk az egyes kistérségeken belüli közúti távolságokkal, és e sugár megtételéhez szükséges időt tekintjük saját távolságnak.

Az EU15, szerb, román, szlovák, ukrán állampolgárok esetén a kiszámolt kistérségi potenciál értékeket térképen ábrázoltuk 2001-ben és 2008-ban (8. ábra).

\section{8. ÁBRA \\ A potenciálmodellek eredményei \\ (Results of Potential Models) \\ Szerb állampolgárok, 2001; 2008}
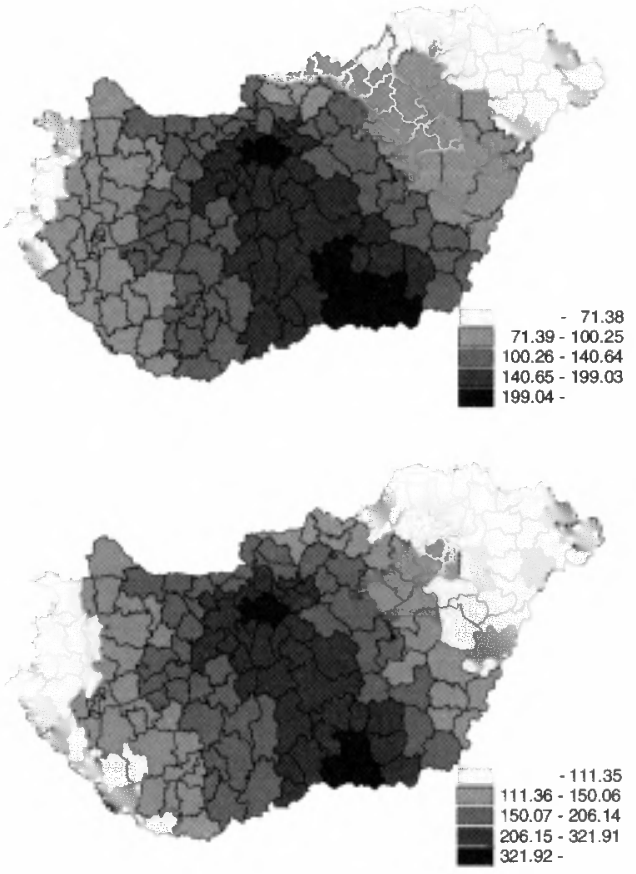
Tóth Géza - Kincses Áron : A hazánkba bevándorlók területi elhelyezkedésének vizsgálata.

Tér és Társadalom 23. évf. 2009/4. 61-81. p.

78 Tóth Géza-Kincses Áron

TÉT XXIII. évf. 2009 - 4

Román állampolgárok, 2001; 2008
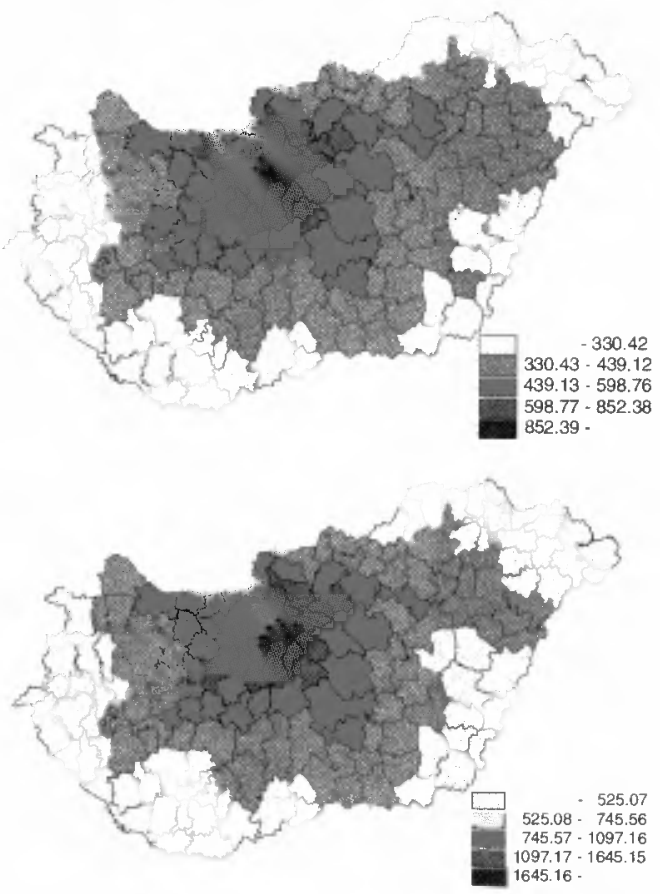

Szlovák állampolgárok, 2001; 2008

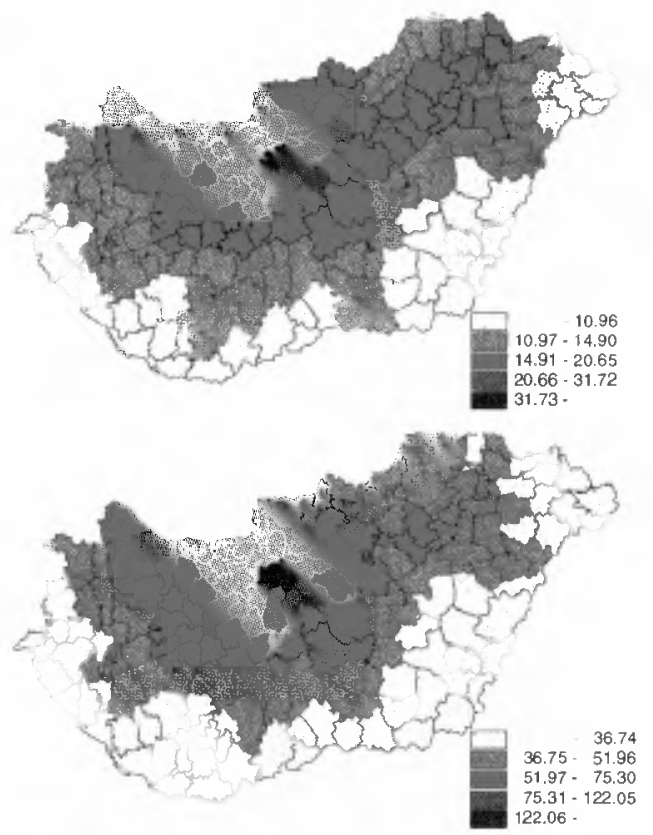


Tóth Géza - Kincses Áron : A hazánkba bevándorlók területi elhelyezkedésének vizsgálata. Tér és Társadalom 23. évf. 2009/4. 61-81. p.

Ukrán állampolgárok, 2001; 2008

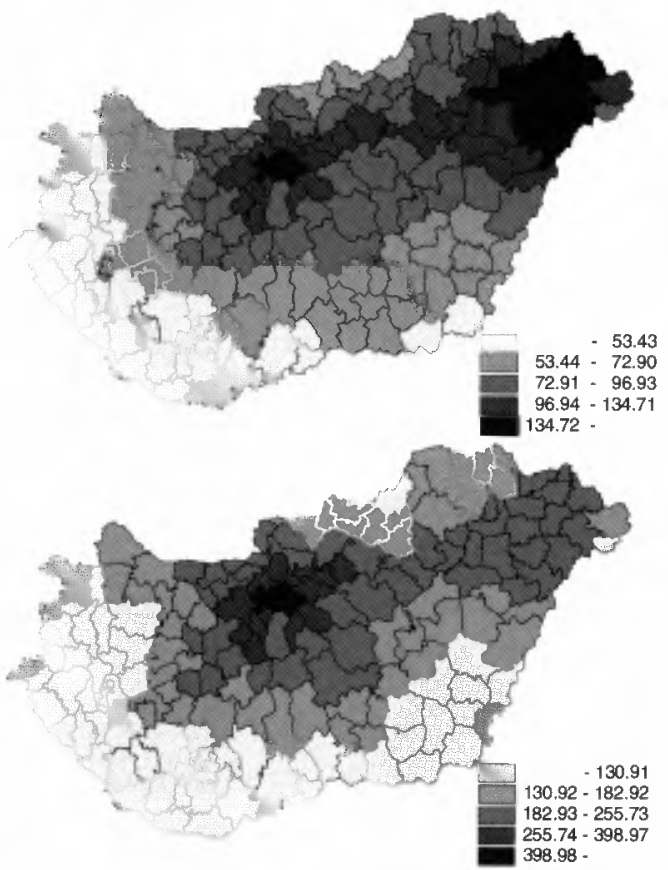

EU15 állampolgárok, 2001; 2008
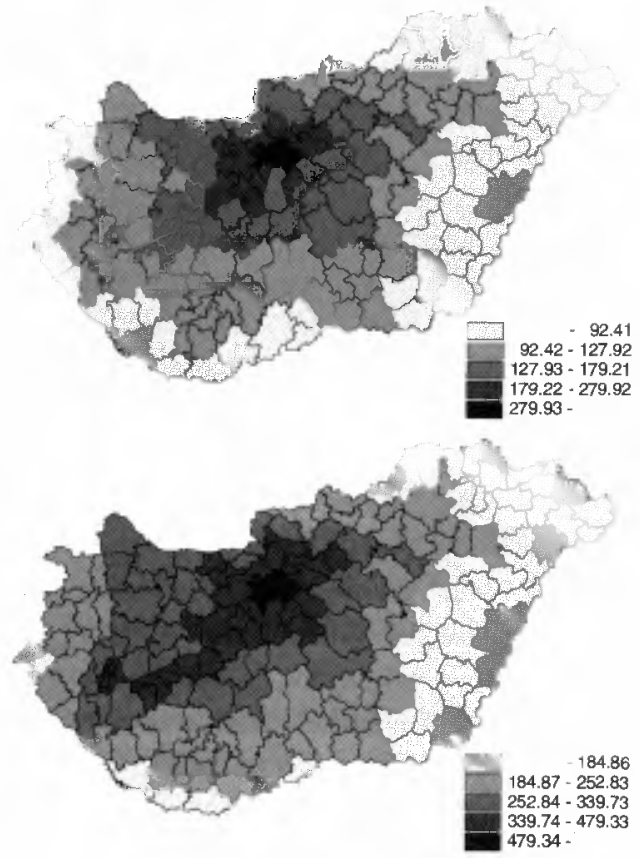

Forrás: Saját szerkesztés. 
Tóth Géza - Kincses Áron : A hazánkba bevándorlók területi elhelyezkedésének vizsgálata.

Tér és Társadalom 23. évf. 2009/4. 61-81. p.

Az ábrákból leolvasható, hogy más-más a kistérségek helyzetpotenciál eloszlása a különböző országokból érkező állampolgárok esetén. A küldő országok és Budapest közötti „csatornákat” fedezhetünk fel a Romániából érkezettek kivételével, akik számára elsődlegesen Budapest és környéke jelent vonzást, de az egész ország területén megtalálhatóak. Az ukránoknál kelet-nyugat irányú, az osztrákok esetén nyugat-keleti, míg a szerbeknél és a szlovákoknál észak-déli erős potenciálfolyosókat tapasztalhatunk.

\section{Összegzés}

A külföldiek domináns része Budapestre és vonzáskörzetébe telepszik le hazánkban, kisebb hányaduk a határ menti kistérségekben, illetve a Balaton környékén él. A szomszédos országokból Magyarországon tartózkodó külföldiek számára egyöntetủen Budapest és Pest megye jelent vonzó célpontot, emellett előnyben részesítik az állampolgárságuknak megfelelő országhoz közelebb eső kistérségeket, fóként a román, ukrán és szerb határ közelében.

$\mathrm{Az}$ útelemzés során a vizsgálatba bevont változóink együttesen döntő részben megmagyarázzák a megfeleló állampolgárságú külföldi lakosság lakónépességen beluili arányát. Másrészt viszont állampolgárságok szerint jelentős eltéréseket találunk a magyarázó változók súlyában. Elemzésünk egyik legfontosabb megállapítása, hogy a külföldiek 2001 és 2008 közötti átlagos arányára a legjelentősebb magyarázó erővel minden esetben a régebben érkezett migránsok aránya hat. Azaz, az újonnan érkezők a már meglévő struktúra szerint oszlanak meg.

Az elérhetőségi mutatók hatása valamennyi állampolgári csoport esetében nem közvetlenül érhetô tetten, hanem elsősorban a társadalmi-gazdasági helyzetet leíró mutatókon keresztül.

A potenciálvizsgálatok során megállapítottuk, hogy a küldő országok és Budapest közötti „csatornákat” fedezhetünk fel a Romániából érkezettek kivételével, akik számára elsődlegesen Budapest és környéke jelent vonzást, de az egész ország területén megtalálhatóak.

\section{Jegyzet}

${ }^{1}$ A tanulmány megjelenését az MTA Bolyai Ösztöndíj támogatta.

\section{Irodalom}

Anderson, J.-O'Down, L. (1999) Borders, Border Regions and Territoriality: Contradictory Meaning, Changing Significance. - Regional Studies. 7. 593-604. o.

Borjas, G.J. (1996) Labour economics. McGrawHill, New York. 279-231. o. 
Tóth Géza - Kincses Áron : A hazánkba bevándorlók területi elhelyezkedésének vizsgálata. Tér és Társadalom 23. évf. 2009/4. 61-81. p.

TÉT XXIII. évf. 2009 『 4 A hazánkba bevándorlók ... 81

Hansen, N. (1977) Border Regions: a Critique of Spatial Theory and European Case Studies. - Annals of Regional Science. 11. 1-12. o.

Hansen, W.G. (1959). How accessibility shapes land use. - Journal of the American Institute of Planners. 2, 73-76. o.

Hardi T (2008) A határtérség térszerkezeti jellemzői. - Tér és Társadalom. 3. 3-25. o.

Hatton, T.J.-Williamson, J.G. (2005) Global Migration and the World Economy: Two Centuries of Policy and Performance. MIT Press, Cambridge.

Németh N. (2008) Fejlődési tengelyek az új hazai térszerkezetben. Az autópálya-hálózat szerepe a regionális tagoltságban. PhD értekezés. ELTE Regionális Tudományi Tanszék, Budapest.

Nijkamp, P. (1998) Moving Frontiers: a Local-global Perspective. Vrije Universiteit of Amsterdam, Faculty of Business Administration and Econometrics, Amsterdam. Research Memorandum no. 22.

Székhelyi M.-Barna I. (2008) Túlélökészlet az SPSS-hez. Többváltozós elemzési technikákról társadalomkutatók számára. Typotex Kiadó, Budapest.

Tóth, G.-Kincses, Á. (2007) Elérhetöségi modellek. - Tér és Társadalom. 3. 51-87. o.

Van Geenhuizen, M.-Ratti, R (2001) Gaining Advantage from Open Borders. An active Space for Regional Development. Ashgate, Aldershot.

\section{EXAMINING REGIONAL DISTRIBUTION OF IMMIGRANTS IN HUNGARY}

\section{GÉZA TÓTH - ÁRON KINCSES}

The study examines the regional peculiarities of immigration in Hungary. We reveal the reasons for immigration and the national differences thereof. We analyse the relations between the share of migrants and the road availability with the help of a road analysis method. We examine the relations between immigrants and migrants living already in Hungary, and using a potential method we reveal the spatial disparities of the distribution of immigrants at micro-regional level. 